\title{
REVIEW
}

\section{Genomic insights into early-onset obesity}

Hélène Choquet* and David Meyre*

\begin{abstract}
The biological causes of childhood obesity are complex. Environmental factors, such as massive marketing campaigns for food leading to over-nutrition and snacking and the decline in physical activity, have undoubtedly contributed to the increased prevalence of overweight and obesity in children, but these cannot be considered as the only causes. Susceptibility to obesity is also determined to a great extent by genetic factors. Furthermore, molecular mechanisms involved in the regulation of gene expression, such as epigenetic mechanisms, can increase the risk of developing early-onset obesity. There is evidence that early-onset obesity is a heritable disorder, and a range of genetic factors have recently been shown to cause monogenic, syndromic and polygenic forms of obesity, in some cases interacting with environmental exposures. Modifications of the transcriptome can lead to increased adiposity, and the gut microbiome has recently been shown to be key to the genesis of obesity. These new genomic discoveries complement previous knowledge on the development of earlyonset obesity and provide new perspectives for research on the complex molecular and physiological mechanisms involved in this disease. Personalized preventive strategies and genomic medicine may become possible in the near future.
\end{abstract}

\section{Epidemiology of early-onset obesity}

Childhood obesity is one of the most serious public health challenges of the 21st century. This global health problem is gradually affecting both developed and developing countries, particularly in urban settings. In the United States, childhood overweight and childhood obesity are defined as a body mass index (BMI; (Weight in $\mathrm{kg}) /(\text { Height in } \mathrm{m})^{2}$ ) greater than or equal to the 85th and 95th percentile for gender and age, respectively [1].

${ }^{*}$ Correspondence: helene@good.ibl.fr, meyre@good.ibl.fr

CNRS UMR8199, Institute of Biology, Pasteur Institute, 1 Pr Calmette Street, 59000 Lille, France
In Europe, the European Children Obesity Group defined childhood overweight and childhood obesity as a BMI greater than or equal to 90th percentile to 97th percentile for gender and age [2]. A reference population has been established to propose an international standard definition for childhood overweight and childhood obesity [3]. The prevalence of overweight and obesity in childhood is increasing worldwide at an alarming rate: today, about one in three children and adolescents is overweight or obese in the United States; over the past three decades, the prevalence of obesity has tripled for children 2 to 5 years old and youths 12 to 19 years old, and has quadrupled for children 6 to 11 years old [4]. According to the World Health Organization and to the International Obesity Task Force, more than 155 million children and adolescents worldwide are overweight and 40 million are clearly obese.

Early-onset obesity is associated with an increased incidence of adult obesity [5], type 2 diabetes [6], nonalcoholic fatty liver disease [7] and cardiovascular risk factors [8]. Obese children have an increased risk of developing obesity-related co-morbidities, such as orthopedic, ophthalmologic and renal complications [9], respiratory diseases such as obstructive sleep apnea [10], and psychosocial impairment [11]. Obesity-associated complications are now believed to be leading, for the first time in modern history, to a decrease in life expectancy of 2 to 5 years for the US generation that is currently young [12].

Today, medical and behavioral interventions as treatment for obesity in childhood remain scarce and largely ineffective. There are currently three main treatment modalities for obesity: lifestyle modifications, pharmacotherapy and bariatric surgery. The cornerstone of lifestyle modifications includes changes to dietary and exercise habits [13]. However, less than $5 \%$ of the obese people who follow these recommendations effectively lose weight and maintain that weight loss [14]. The longterm safety and efficacy of the anti-obesity drugs (orlistat and sibutramine) have not been determined in children or adolescents, mainly because pharmacotherapy is not routinely proposed as a treatment for childhood obesity [15]. Bariatric surgery is a new treatment for morbid obesity in children but the relevance of an invasive surgery procedure in childhood or adolescence is still 
under debate [16]. A recent study [17] reported the first case of laparoscopic sleeve gastrectomy successfully performed in a 6-year-old morbidly obese child. Because of the lack of efficiency of the current approaches to reverse childhood obesity, prevention was proposed as the first line of treatment in 2003 by the American Academy of Pediatrics [18]. In its policy statement, the Academy promoted breastfeeding, healthy eating habits and physical activity and encouraged limitation of television viewing. However, current prevention programs have had little success and have proven ineffective in reversing the rising rates of childhood obesity [19]. These disappointing observations reveal the urgent need to better understand the complex molecular and physiologic mechanisms involved in human obesity in order to propose better disease prevention and care.

\section{Early-onset obesity is a heritable disorder}

The epidemic of obesity is attributed to recent environmental changes. Easy access to high-energy palatable food, combined with decreased physical activity levels, have undoubtedly had a major role in the global increase in the prevalence of early-onset obesity [20]. Beyond 'the big two', other putative environmental contributors to the recent obesity epidemic have been proposed, such as an obesity-prone intrauterine environment, assortative mating among obese individuals, decreasing sleep duration, infections and low-grade inflammation or the increasingly controlled ambient temperature [21]. However, if these factors are responsible for the global shift in BMI distribution, genetic factors must explain most of the inter-individual differences in obesity risk observed in populations (in other words, where each individual sits on the BMI distribution) [22]. In fact, the risk of obesity in a child is ten times higher if both parents are obese than if both parents are of normal weight [23].

Heritability represents the proportion of phenotypic variation in a population that is attributable to genetic variation among individuals. According to twin and family studies, heritability estimates for BMI during childhood or adolescence are between 0.20 and 0.86 [22,24-29]. Longitudinal studies have demonstrated that heritability estimates tend to increase from childhood to pre-adolescence $[26,29]$ and from pre-adolescence to adolescence [27], probably because individuals at genetic risk for obesity increasingly select 'obesogenic' environments (environments that promote gaining weight) correlated with their genetic propensities. In addition, physical activity reduces the influence of genetic factors on BMI in young adults, and it is likely that these results are transposable to children or adolescents [30]. Even if heritability estimations of BMI are similar in boys and girls, some sets of genes explaining the BMI variation may, at least in part, be different in males and females
[24]. The values of heritability for BMI in childhood remain high even in the obesogenic environment currently present in developed countries such as the US [22,28].

\section{Monogenic forms of early-onset obesity}

Several single-gene disorders result in severe, early-onset obesity. These monogenic forms of early-onset obesity show the biological importance of the mutant gene in body-weight control. The main genes affected in these monogenic disorders (leptin $(L E P)$, leptin receptor $(L E P R)$, pro-opiomelanocortin $(P O M C)$, prohormone convertase 1 (PCSK1), melanocortin 4 receptor $(M C 4 R)$, brain-derived neurotrophic factor $(B D N F)$ and neurotrophic tyrosine kinase receptor type 2 (NTRK2)) encode hormones or neurotransmitters and their hypothalamic receptors of the highly conserved leptin-melanocortin pathway, which is critical for the regulation of food intake and body weight [31]. A case of Single-minded homolog 1 (SIM1) haploinsufficiency has been reported in one patient with early-onset obesity [32]. The SIM1 gene encodes a transcription factor essential for formation of the supraoptic and paraventricular (PVN) nuclei of the hypothalamus. Additional evidence of a role of SIM1 haploinsufficiency in human obesity was provided by the finding of rare non-synonymous SIM1 mutations enriched in severely obese patients in comparison with lean individuals [33]. Recent data have linked SIM1 haploinsufficiency with Mendelian obesity and a Prader-Willilike syndrome (F Stutzmann et al., personal communication). The loss of function $\mathrm{C} 256 \mathrm{Y}$ mutation in the wingless-type MMTV integration site family, member 10B (WNT10B) gene, which encodes a signaling protein that negatively regulates adipocyte differentiation as part of the Wnt signaling pathway, was shown to co-segregate with overweight or obesity in one pedigree, but further studies are needed to confirm the link between this gene and monogenic early-onset obesity [34].

The majority of genes involved in monogenic forms of early-onset obesity were identified as candidate genes on the basis of previous evidence from physiological studies and animal models. Children with a strong family history of obesity and issued from consanguineous families are of particular interest for genetic diagnosis of early-onset obesity. Monogenic obesity forms are frequently accompanied by additional clinical features (for example, severe hyperphagia, intestinal troubles) and normal development, except for BDNF, SIM1 and NTRK2 deficiencies, which are associated with cognitive impairment, behavioral problems or syndromic features $[35,36]$.

The focus on the leptin-melanocortin pathway as a target for pharmacological intervention in patients with severe obesity turned out to be effective. The best illustration is certainly the case of a child with congenital leptin deficiency who was treated with subcutaneous 
injections of recombinant human leptin, leading to the correction of all the phenotypic abnormalities seen in this patient [37].

\section{Syndromes that include early-onset obesity}

Complex obesity syndromes are defined as Mendelian disorders with obesity as a clinical feature that are also associated with mental retardation, dysmorphic features and organ-specific developmental abnormalities. Over 30 syndromes that include obesity have been identified but only some of them, such as the WAGR (Wilm's tumor, aniridia, genitourinary anomalies and mental retardation) [38], Prader-Willi [39], Bardet-Biedl [40], Alström [41] and Cohen [42] syndromes, have been associated with early-onset obesity.

The genetic basis for these syndromic forms of earlyonset obesity has been elucidated, revealing an important genetic heterogeneity. Molecular genetic analyses of individuals with WAGR syndrome have revealed that the Wilm's tumor 1 (WT1) and Paired box 6 (PAX6) genes are involved with this syndrome, but deletions in the $B D N F$ gene were recently shown to explain the phenotype of obesity found in a subgroup of patients with the WAGR syndrome [38]. Prader-Willi syndrome (PWS) can have several etiologies but it is always associated with loss of expression of paternally transmitted genes on 15q11-13. A microdeletion of the HBII-85 small nucleolar RNAs (snoRNAs) caused the PWS phenotype in a child [43] and recently another de novo microdeletion at chromosome 15q11-13 that encompasses non-coding snoRNAs was identified in a patient affected with hyperphagia, early-onset obesity, hypogonadism and mild learning difficulties but diagnosed negative for PWS [44]. Bardet-Biedl syndrome (BBS) has extensive genetic heterogeneity and so far 14 genes have been associated with it [40]. The BBS proteins are implicated in the function of primary cilia and intraflagellar transport [45]. Finally, Alström and Cohen syndromes [41,42] are associated with childhood truncal obesity and have a unique genetic cause. For Alström syndrome, children usually have normal birth weight but become obese during their first year, resulting in childhood truncal obesity [41]. ALMS1, the only gene currently known to be associated with Alström syndrome [41], codes for a protein involved in the normal functioning of primary cilia. The only gene so far involved in Cohen syndrome is $\mathrm{COH} 1$, which encodes a transmembrane protein of unknown function [42].

\section{Polygenic forms of early-onset obesity: early studies \\ Linkage studies}

Genome-wide linkage scans involve the genotyping of families using highly polymorphic markers that are positioned across the whole genome, followed by a calculation of the degree of linkage of the marker to a disease trait. Genome-wide linkage approaches led to the successful identification of numerous genes involved in Mendelian human diseases, but their relevance in the identification of genes contributing to complex diseases has been more controversial [46]. More than 60 linkage studies for obesity-related traits were published in the 2006 update of the Obesity Map [47], but only three studies involved pedigrees with children or adolescents [48-50].

The only significant evidence of linkage for childhood obesity was obtained on chromosome 6q22.31-q23.2 in 115 French pedigrees [49]. Subsequent positional cloning led to the identification of a three-allele risk haplotype (K121Q, IVS20delT-11, A $\rightarrow$ G +1044TGA; abbreviated to QdelTG) in the ectonucleotide pyrophosphatase/phosphodiesterase 1 (ENPP1) gene that showed association with childhood obesity and contributed in part to the observed linkage of chromosome $6 \mathrm{q}$ with childhood obesity [51]. The haplotype was associated with increased serum levels of soluble ENPP1 protein in children. The function of the gene can be directly related to obesity: ENPP1 inhibits insulin receptor activity [52], and up- or downregulation of ENPP1 expression in liver is associated with decreased or enhanced insulin sensitivity, respectively, in rodents [53,54]. Insulin resistance in children is a strong predictor of future weight gain $[55,56]$. The association of the ENPP1 risk haplotype with childhood obesity has so far been replicated in only one (Bottcher et al.) of two studies [57,58], and further replication studies followed by a large meta-analysis are needed to provide an unequivocal confirmation. As observed for other complex diseases, linkage approaches have been mostly unsuccessful in identifying new obesity genes. Statistical simulations predict that odds ratios (ORs) must be high (more than 2) to induce significant peaks of linkage in modest family sample sets, making genome-wide linkage scans more relevant to identifying gene variants with high ORs [59].

\section{Candidate gene association studies}

Candidate gene approaches have been performed for hundreds of genes, and genetic variations in at least 127 candidates have been associated with obesity in at least one study according to the 2006 update of the Human Obesity Map [47]. However, the risk of reporting a false positive result is extremely high in single underpowered studies as a result of the 'winner's curse' effect (the 'winner's curse' effect leads to an over-representation of genetic studies with positive results in the literature), and only three genes have reached a convincing level of association with childhood and adult obesity using metaanalytic strategies. Two coding non-synonymous gain-offunction polymorphisms (V103I and I251L) in MC4R 
have been reproducibly associated with protection from obesity onset in both children and adults. A metaanalysis of 15 independent studies was performed for the I251L polymorphism (OR $=0.38$ to $\left.0.71, P=3 \times 10^{-5}\right)$, and 37 independent studies were collected for the study of the V103I polymorphism $(\mathrm{OR}=0.71$ to 0.88 , $P<0.0001)[60,61]$. More recently, the non-synonymous variants N221D and the Q665E-S690T cluster in the PCSK1 gene were consistently associated with obesity in adults and children in eight independent case-control or family-based cohorts of European ancestry $\left(P_{\text {overall }}=7 \times 10^{-8}\right.$ and $P_{\text {overall }}=2 \times 10^{-12}$, respectively) [62]. Functional analysis showed a $10.4 \%$ reduction of the N221D-mutant $\mathrm{PC} 1 / 3$ protein catalytic activity [62]. The association of the N221D variant with BMI and obesity was confirmed in two large adult European populations [63,64]. MC4R and PCSK 1 can be considered as relevant candidate genes for polygenic studies because these two genes contribute to monogenic forms of early-onset obesity [65-67]. As the endocannabinoid receptor 1 (CNR1) is the target of the anti-obesity drug Accomplia, a candidate gene approach was performed with the CNR1 gene and led to the identification of two intronic polymorphisms (rs806381 and rs2023239) that were consistently associated with BMI level and childhood or adult obesity risk in a meta-analysis of 5,750 people [68]. Five independent studies in adults confirmed the potential role of polymorphisms at the CNR1 locus in body-weight control [69-73].

\section{Recent genomic research}

\section{The genome-wide association study revolution}

The dramatic progress in the human genome single nucleotide polymorphism (SNP) map through the International HapMap Consortium [74], combined with the development of new methods for high-throughput genotyping using SNP microarrays, have made comprehensive genome-wide association studies (GWASs) possible [75]. In the past 3 years, genome-wide association studies have led to the identification of more than 250 genetic loci that are reproducibly associated with complex disease-related traits [76], including several loci associated with obesity risk and BMI variation [77].

The first GWAS for early-onset obesity was published in 2007 [78]. DNA array information was available for 487 extremely obese young German people and 442 healthy lean German controls, and replication studies were performed with 644 independent families with at least one offspring and both parents obese [78]. This modestly powered but pioneering study identified variation in the Fat mass and obesity associated (FTO) gene as consistently associated with early-onset obesity and confirmed $F T O$ as a major contributor to polygenic obesity - FTO had previously been linked by GWAS or population structure approaches to type 2 diabetes and obesity susceptibility [79-81].

In 2009, a GWAS was published for early-onset and morbid adult obesity in a French population. DNA arrays were genotyped in 685 obese children, 695 morbidly obese adults (obese patients were from families with a high recurrence of obesity), 685 lean children and 731 lean adults. The best association signals were further investigated in 14,186 European adults or children [82]. This study independently confirmed at the genome-wide level of significance the association of variants in FTO and near MC4R with obesity risk and BMI variation $\left(P_{\text {overall for obesity risk and BMI variation }}=1 \times 10^{-28}\right.$ and $5 \times 10^{-15}$, respectively). The association signal near $M C 4 R$ has been previously identified in a GWAS meta-analysis for BMI in European adults [83] and in a GWAS for waist circumference in Asian Indians [84]. Three new obesity-predisposing loci (Niemann-Pick disease, type C1 (NPC1), the transcription factor c-MAF $(M A F)$ and phosphotriesterase-related (PTER)) were identified at the genomewide level of significance in the whole sample [82].

Very recently, a joint analysis of GWAS for early-onset extreme obesity in French and German study groups identified gene variants in or near FTO, MC4R, transmembrane protein 18 (TMEM18), serologically defined colon cancer antigen 8 (SDCCAG8) and TRF1-interacting ankyrin-related ADP-ribose polymerase/methionine sulfoxide reductase A (the TNKS/MSRA gene cluster) [85]. The TMEM18 locus was previously identified as associated with adult BMI in the international GIANT consortium [64], and the TNKS/MSRA gene cluster had previously been linked to waist circumference in adults [86]. Interestingly, some of the new loci associated with BMI in adults and identified by GWAS approaches $[64,80,83,87]$ have also been associated with childhood extreme obesity (TMEM18, Glucosamine-6-phosphate deaminase 2 (GNPDA2) and Neuronal growth regulator 1 (NEGR1)) or BMI in children (Insulin induced gene 2 (INSIG2), FTO, MC4R, TMEM18, GNPDA2, NEGR1, $B D N F$, and Potassium channel tetramerization domain containing 15 (KCTD15)) [64,88]. Several of the likely causal obesity-predisposing genes are highly expressed or known to act in the central nervous system, emphasizing, as with Mendelian forms of obesity, a key role for central regulation of food intake in predisposition to obesity [64].

\section{Genome structural variation and early-onset obesity}

Humans are usually diploid and they have two copies of each autosomal region, one per chromosome. This may differ for particular genetic regions as a result of structural variation, such as copy number variation $(\mathrm{CNV})$, which includes deletion, duplication, translocation and inversion of chromosomes. CNVs are either 
inherited or caused by de novo mutation. It has recently been suggested that common CNVs could explain a substantial part of heritability in complex diseases [89]. A common $45-\mathrm{kb}$ deletion upstream of the NEGR1 gene tagged by the polymorphism rs 2815752 has been identified as associated with BMI variation in adults by a GWAS approach [64]. This deletion was consistently associated with BMI variation and risk for extreme obesity in children $[64,88]$.

Two reports have recently highlighted the contribution of rare CNVs to the genetic architecture of early-onset obesity [90,91]. A recent study including 300 Caucasians with severe early-onset obesity (143 of whom also had developmental delay) and 7,366 controls showed that large, rare chromosomal deletions (located on chromosomes $3,6,8,10,11,15,16,17$ and 22) were twice as frequent in patients as in controls [90]. A 16p11.2 deletion previously associated with autism [92,93], schizophrenia [94] or mental retardation [95] was carried by five patients with severe early-onset obesity and developmental delays and was the commonest CNV associated with obesity [90]. The association between deletions on chromosome 16p11.2 and obesity and developmental delays was confirmed in a second study involving more than 16,000 people [91]. The presence of deletions at 16 p11.2 led to an incomplete penetrance of obesity in childhood but to a fully penetrant phenotype of severe obesity in adulthood in this study [91]. In the two studies [90,91], 16p11.2 deletions arose de novo in some patients whereas they were inherited in others. The 16p11.2 deletions accounted for $0.7 \%$ of morbid obesity cases without developmental features and were the second most frequent genetic cause of obesity after point mutations in MC4R [91]. An inverse phenotype of underweight has been observed in carriers of duplications on chromosome 16p11.2, confirming a key role of this region in body weight regulation [96].

$\mathrm{CNV}$ analysis has enabled detection of chromosomal regions (including a single gene or a contiguous set of genes) associated with obesity and thus the identification of new candidate genes implicated in disease susceptibility. The 16p11.2 deletion interval identified in these studies encompasses about 30 genes. SH2B adapter protein 1 (SH2B1) is one of these genes and is an excellent candidate gene to link the 16p11.2 deletion to obesity because its encodes a Janus kinase 2 (JAK2)-interacting protein that has been recently proposed as an endogenous enhancer of leptin sensitivity [97]. Disruption of $\mathrm{SH} 2 \mathrm{~B} 1$ in mice induces severe hyperphagia, obesity, severe insulin resistance and hyperleptinemia [97]. Inversely, neuron-specific overexpression of SH2B1 in mice protects against the leptin resistance and obesity that are induced by a high-fat diet [98]. In accordance with the phenotype observed in SH2B1-deficient mice, Bochukova and colleagues observed that carriers of the $16 \mathrm{p} 11.2$ deletion, in addition to obesity, exhibited hyperphagia and severe insulin resistance disproportionate to the degree of obesity [90]. Several GWASs have reproducibly identified $S H 2 B 1$ as a risk locus for common obesity $[64,87]$. These data suggest a key role of the $S H 2 B 1$ gene in the $16 \mathrm{p} 11.2$ deletion-related obesity phenotype, even if we cannot exclude a role for additional genes in the deleted interval.

\section{Gene-environment interactions}

Environmental factors, such as diet, physical activity, age, gender, socio-economic status and ethnicity, among others, have been shown to modulate the risk for obesity [20]. As obesity genetics makes further progress, considerable interest has recently been turned to the potential interactions between obesity-predisposing gene variants and specific environmental situations. A significant interaction between the effects of high-fat diet and FTO genotype on BMI has been reported recently, the observed increase in BMI across FTO genotypes being restricted to people who reported a high-fat diet [99]. An interaction between the Apolipoprotein A-II (APOA2) $-265 \mathrm{~T}>\mathrm{C}$ SNP and high saturated fat in relation to BMI and obesity has been observed in three independent populations [100]. This SNP was not identified by recent GWAS approaches, suggesting that some associations restricted to specific environments can be missed in analyses that do not take into account the modifying effect of environmental co-variables.

An interaction between the FTO obesity risk genotype and physical activity on BMI variation or obesity risk has been consistently reported in nine independent studies including adults and adolescents [99,101-108]. These results strongly suggest that the increased risk of obesity provided by FTO variants can be attenuated through physical activity.

Age and gender can be viewed as specific environmental conditions. Age-dependent associations of gene variants have been reported: the genetic influence of obesity risk common variants in FTO was shown to become progressively stronger across lifespan $[26,109]$, whereas gene variation in PCSK1 had more pronounced effects on BMI level and obesity risk in young than in late adulthood [63]. An age-dependent penetrance of MC4R pathogenic mutations on obesity has been found in multigenerational pedigrees, the effect of mutations on the obesity phenotype being amplified by the development of an 'obesogenic' environment [110].

Females are at higher risk of developing extreme forms of obesity than males. These discrepancies could be explained, at least in part, by female-specific genetic associations or by stronger effect sizes of genetic variants in females. This was observed for the functional 
polymorphism $\mathrm{R} 125 \mathrm{~W}$ in the $\mathrm{TBC} 1$ domain family member 1 (TBC1D1) gene. The effect of this variant on severe obesity risk was restricted to females in two independent populations [111,112]. The observed effect of $M C 4 R$ pathogenic mutations on BMI was about twice as strong in females as in males in two independent populations [110,113].

The well-established negative association between BMI and educational status was not found in MC4R loss-of function mutation carriers, although a significant relationship was seen in MC4R non-mutation carriers of the corresponding pedigrees [110]. These results suggest that a high level of education has no protective effect on obesity risk in the presence of $M C 4 R$ pathogenic mutations.

Recently, the first evidence of ethnic-group-specific association with obesity has been reported. Variants in intronic regions of SIM1 were strongly associated with BMI and obesity risk $\left(P=4 \times 10^{-7}\right)$ in Pima Indians. The SNPs showing strongest association were genotyped in French individuals but no association with obesity was found [114]. As linkage disequilibrium blocks (linkage disequilibrium is the non-random association between alleles at different loci) can vary according to the ethnic background, an approach involving tagging of the SIM1 locus was applied in French Europeans and excluded a major contribution of SIM1 common variants in polygenic obesity susceptibility, a result confirmed by the absence of genome-wide significant association in the SIM1 gene region in recent GWASs [115]. Together, the studies reviewed in this section highlight the complex interplay between genetic susceptibility to obesity and the experienced environment.

\section{Genomics of early-onset obesity The transcriptome}

Differences in the adipose tissue transcriptome have been observed depending on obesity status [116]. A 28-day very low calorie diet in obese patients induced changes in the adipose tissue transcriptome that render their expression pattern closer to the profile of lean people [117]. A 7-day hypercaloric diet induced significant differences in the adipose tissue expression pattern in both lean and obese people. However, six genes were differently expressed in response to overfeeding only in lean people, suggesting that there is a protective mechanism at the molecular level in response to an energy surplus that is lacking in obese patients [118].

A recent study [119] assessed the impact of food intake on gene expression in human peripheral blood. Leonardson and colleagues [119] found that gene-expression variations are strongly connected to clinical traits related to obesity, such as hip circumference, but depend on the nutritional state (fasted or fed). The response to food intake has a significant genetic component and could facilitate the dissection of the underlying causes of obesity. The composition of the diet can also modulate gene expression. High-fat versus low-fat diets have been associated with changes in the hypothalamic transcriptome of mice [120]. Beyond the simple observation of changes in transcriptome according to disease status or diet interventions, adipose gene expression signatures may help differentiate responders from non-responders to low-fat hypocaloric diet and pave the way for future personalized nutritional approaches [121].

Testing DNA markers for association with complex traits at the genome-wide scale is now a reality. However, more information on how variations in DNA affect complex physiological processes may come from transcriptome studies [122]. Gene expression can be used as an intermediary phenotype for complex traits in order to refine the disease phenotype and identify pathways and genes associated with that disease phenotype [123]. By integrating DNA variation and gene expression data in liver (an important tissue involved in metabolic diseases) with the complex trait obesity in segregating mouse populations, and by validating the best candidate genes in knock-out or transgenic mice, Eric Schadt and colleagues [123-126] identified ten causal genes involved in variation of obesity-associated traits. An integrative approach combining gene expression adipose data in humans and mice, genome-wide linkage and association mapping and a gene network approach [127] identified a core network module of genes involved in the inflammatory and immune response as causally associated with obesity-related traits. Although this study [127] did not provide further functional support for candidate obesitysusceptibility genes, the expression quantitative trait locus approach in well targeted tissues is promising and may contribute to increasing the list of causal genes involved in human obesity in the near future.

\section{The gut microbiome}

The gut microbiota can be considered as an environmental factor that regulates fat storage [128]. Significant alterations in the composition of the intestinal microbiota have been identified in obese mice, suggesting that differences in intestinal flora may explain some of the risk for obesity [129]. The proportion of beneficial Bacteroidetes bacteria is lower in obese adult patients than in lean counterparts, and this proportion increases with weight loss induced by a low calorie diet [130]. Whereas individuals from the same families had a closer bacterial community structure than unrelated individuals, a comparable degree of co-variation was found between adult monozygotic and dizygotic twin pairs, suggesting that the gut microbiome does not have a heritable component but is strongly influenced by the environment [131]. A case-control study in Indian children [132] 


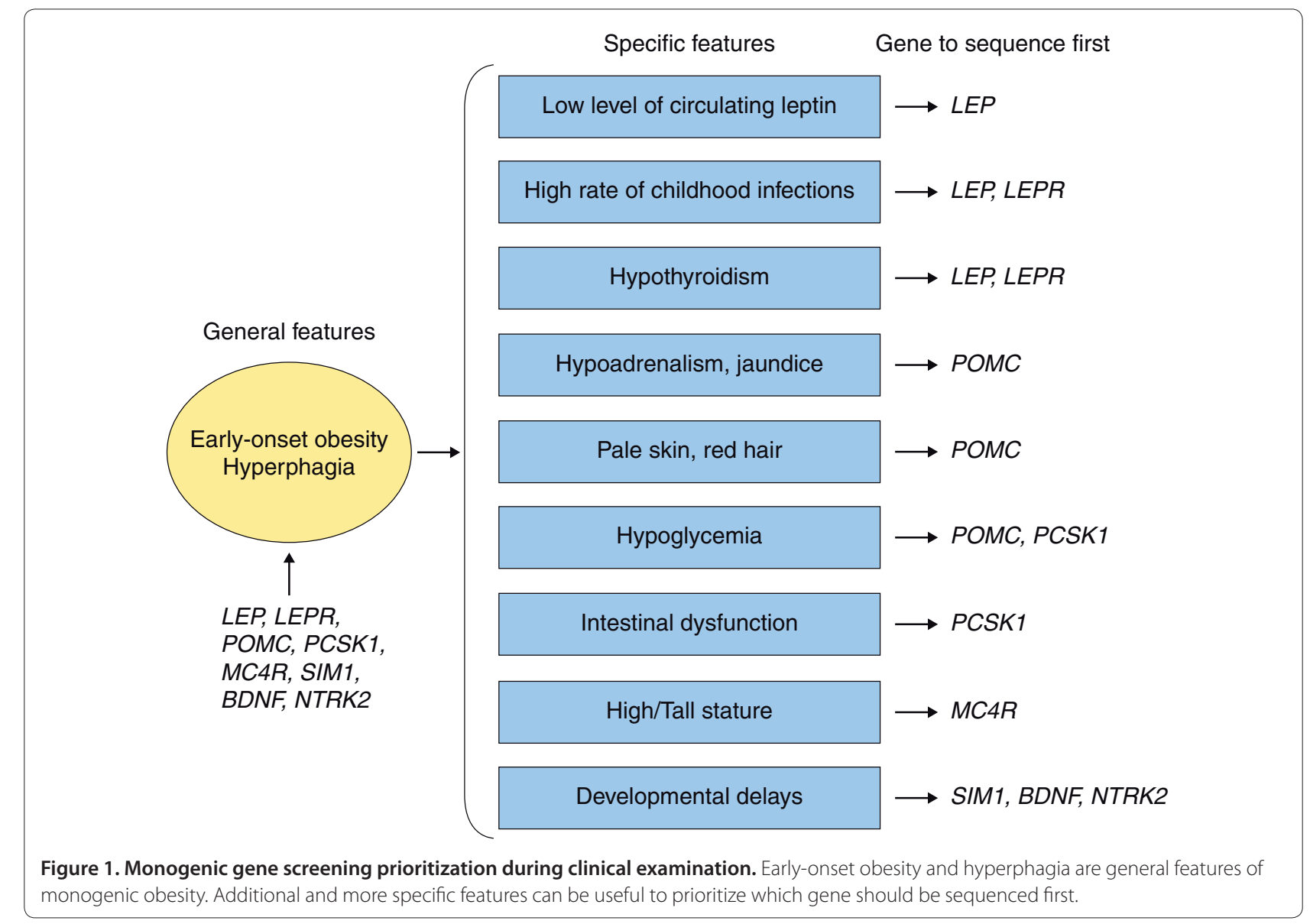

showed quantitative differences in intestinal Faecalibacterium prausnitzii in obese versus lean children. Another study conducted with children [133] found that aberrant intestinal flora enriched in Staphylococcus aureus precedes the development of overweight later in childhood and could be used as a biomarker for the early evaluation of the predisposition to obesity. A recently published human gut microbial catalog of 3.3 million non-redundant microbial genes [134] will help assess with greater accuracy the impact of metagenome diversity on obesity in humans.

\section{Prospects for prediction, prevention and personalized medicine}

Agnostic genome-wide approaches have illuminated unexpected biological pathways and provided a useful list of new candidate genes for further exploration [76]. However, the use of genetic information to predict individual risk of disease in clinical practice remains the 'Holy Grail' for many geneticists [135]. Common variants recently identified by GWASs have a limited predictive value for obesity risk $[136,137]$. International consortia are currently working to increase the list of validated obesity-predisposing SNPs, and sophisticated methodologies (such as machine-learning approaches) are emerging to make better use of SNP information contained in DNA arrays for disease prediction [138]. However, it is likely that common variation will explain only a modest fraction of heritability for early-onset obesity (for example FTO, the strongest predictor of obesity, is responsible for only $1 \%$ of the total heritability) [139].

These results re-emphasize the importance of monogenic obesity in elucidating the heritability of obesity because rare deleterious mutations in the eight wellestablished monogenic obesity genes (LEP, LEPR, POMC, PCSK1, MC4R, BDNF, SIM1 and NTRK2) could explain up to $10 \%$ of cases with early-onset extreme obesity. Mutations in these single genes are sufficient by themselves to cause a strong effect on phenotype. People carrying these mutations have severe hyperphagia and early-onset obesity but also some other specific features (such as a low level of circulating leptin despite severe obesity, a susceptibility to infections, intestinal dysfunction, reactive hypoglycemia, red hair and pale skin and adrenal insufficiency) that can guide gene sequencing approaches (Figure 1). 


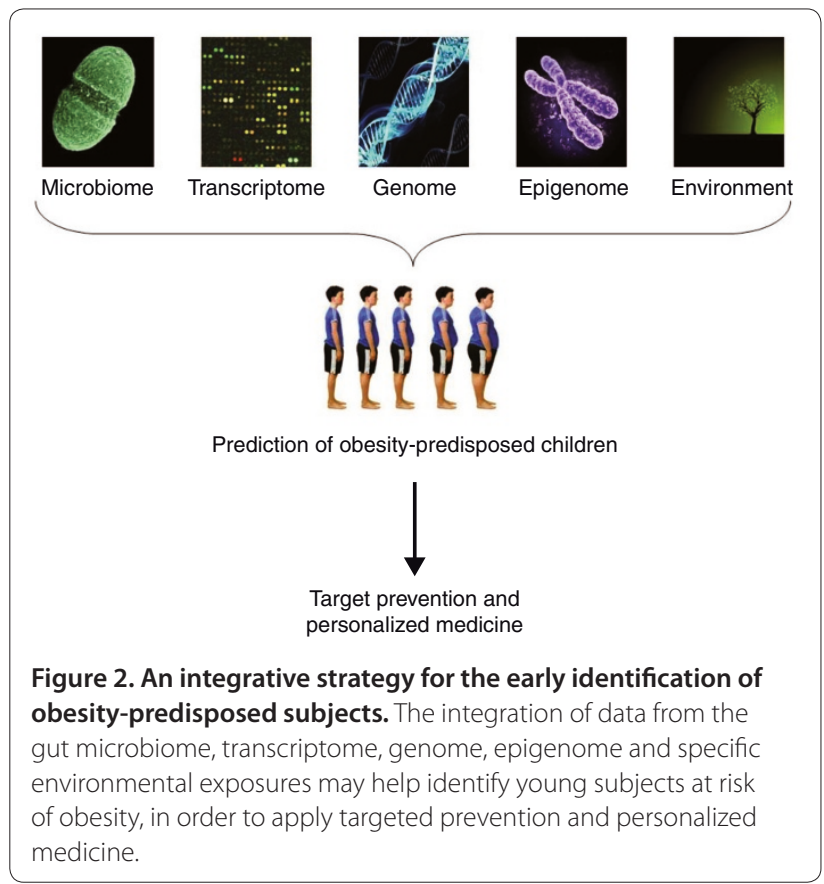

Early diagnosis is fundamental for personalized prevention and effective therapeutic management. The most effective preventive strategy for these monogenic mutation carriers may be stringent restriction of food access. This will require the training and active participation of the parents. Beyond the eight currently known genes, the high occurrence of Mendelian patterns of inheritance observed in multigenerational pedigrees with extreme obesity together with the large fraction of unexplained 'missing' heritability [139] suggests that the causes of many monogenic cases remain to be elucidated [140].

Several innovative strategies may soon lead to a more exhaustive picture of monogenic obesity. High-resolution homozygosity mapping in large consanguineous pedigrees is a powerful approach to discovering new obesity loci with a recessive mode of inheritance, as recently exemplified by syndromic forms of obesity [141]. Full exome capture (an efficient strategy to selectively sequence the coding regions of the human genome) and parallel sequencing strategies in carefully selected unrelated cases and controls have proven successful for gene identification [142], and this approach should be successfully extended in the future to pedigrees with extreme obesity and a Mendelian pattern of inheritance. Genome-wide studies of structural variation in pedigrees or large case-control series followed by a systematic resequencing approach for genes located in genome structural variation intervals may help to identify additional Mendelian obesity genes.

Apart from Mendelian forms of obesity, the use of genetic information alone will provide only limited predictive value in classifying young people at high risk for the development of childhood obesity. As summarized here, additional factors, such as environmental conditions, the transcriptome, the epigenome and the gut metagenome, can affect future obesity or response to dietary interventions. Further work is now needed to achieve a successful integration of all these sources of data to enable us to identify young people at risk for obesity and personalize preventive strategies (Figure 2) [143].

\section{Abbreviations}

BDNF, brain-derived neurotrophic factor; BMI, body mass index; CNR1, endocannabinoid receptor 1; CNV, copy number variation; ENPP1, ectonucleotide pyrophosphatase/phosphodiesterase; FTO, Fat mass and obesity associated; GWAS, genome-wide association study; LEP, leptin; MC4R, melanocortin 4 receptor; NEGR1, Neuronal growth regulator 1; NTRK2, neurotrophic tyrosine kinase receptor type 2; PCSK1, prohormone convertase 1; PWS, Prader-Willi syndrome; POMC, pro-opiomelanocortin; SH2B1, SH2B adapter protein 1; SIM1, Single-minded homolog 1; SNP, single nucleotide polymorphism; TMEM18, transmembrane protein 18; WAGR, Wilm's tumor, aniridia, genitourinary anomalies and mental retardation.

\section{Competing interests}

The authors declare that they have no competing interests.

\section{Authors' contributions}

Both authors contributed to the conception and production of the manuscript and approved the final version.

\section{Acknowledgements}

We thank Jean-Claude Chèvre, Nabila Bouatia-Naji and Guillaume Pare for helpful comments on the manuscript.

Published: 23 June 2010

\section{References}

1. Chinn S: Definitions of childhood obesity: current practice. Eur J Clin Nutr 2006, 60:1189-1194.

2. Poskitt EM: Defining childhood obesity: the relative body mass index (BMI). European Childhood Obesity group. Acta Paediatr 1995, 84:961-963.

3. Cole TJ, Bellizzi MC, Flegal KM, Dietz WH: Establishing a standard definition for child overweight and obesity worldwide: international survey. BMJ 2000, 320:1240-1243.

4. Daniels SR, Jacobson MS, McCrindle BW, Eckel RH, Sanner BM: American Heart Association Childhood Obesity Research Summit: executive summary. Circulation 2009, 119:2114-2123.

5. Whitaker RC, Wright JA, Pepe MS, Seidel KD, Dietz WH: Predicting obesity in young adulthood from childhood and parental obesity. N Engl J Med 1997, 337:869-873.

6. Bhargava SK, Sachdev HS, Fall CH, Osmond C, Lakshmy R, Barker DJ, Biswas SK, Ramji S, Prabhakaran D, Reddy KS: Relation of serial changes in childhood body-mass index to impaired glucose tolerance in young adulthood. N Engl J Med 2004, 350:865-875.

7. De Bruyne RM, Fitzpatrick E, Dhawan A: Fatty liver disease in children: eat now pay later. Hepatol Int 2010, 4:375-385.

8. Baker JL, Olsen LW, Sorensen TI: Childhood body-mass index and the risk of coronary heart disease in adulthood. N Eng/ J Med 2007, 357:2329-2337.

9. Eknoyan G: Obesity, diabetes, and chronic kidney disease. Curr Diab Rep 2007, 7:449-453.

10. Arens $\mathrm{R}$, Muzumdar $\mathrm{H}$ : Childhood obesity and obstructive sleep apnea syndrome. J Appl Physiol, 108:436-444.

11. Zeller MH, Modi AC: Predictors of health-related quality of life in obese youth. Obesity (Silver Spring) 2006, 14:122-130.

12. Olshansky SJ, Passaro DJ, Hershow RC, Layden J, Carnes BA, Brody J, Hayflick L, Butler RN, Allison DB, Ludwig DS: A potential decline in life expectancy in the United States in the 21st century. N Engl J Med 2005, 352:1138-1145.

13. Cummings S, Parham ES, Strain GW: Position of the American Dietetic Association: weight management. J Am Diet Assoc 2002, 102:1 145-1155. 
14. Miller WC: How effective are traditional dietary and exercise interventions for weight loss? Med Sci Sports Exerc 1999, 31:1129-1134.

15. Bessesen DH: Update on obesity. J Clin Endocrinol Metab 2008, 93:2027-2034.

16. Inge $\mathrm{TH}$, Xanthakos SA, Zeller MH: Bariatric surgery for pediatric extreme obesity: now or later? Int J Obes (Lond) 2007, 31:1-14.

17. Dan D, Harnanan D, Seetahal S, Naraynsingh V, Teelucksingh S: Bariatric surgery in the management of childhood obesity: should there be an age limit? Obes Surg 2010, 20:114-117.

18. Krebs NF, Jacobson MS: Prevention of pediatric overweight and obesity. Pediatrics 2003, 112:424-430.

19. Birch LL, Ventura AK: Preventing childhood obesity: what works? Int J Obes (Lond) 2009, 33 Suppl 1:S74-S 81.

20. Bell CG, Walley AJ, Froguel P: The genetics of human obesity. Nat Rev Genet 2005, 6:221-234

21. McAllister EJ, Dhurandhar NV, Keith SW, Aronne $L$, Barger J, Baskin M, Benca RM, Biggio J, Boggiano MM, Eisenmann JC, Elobeid M, Fontaine KR, Gluckman P, Hanlon EC, Katzmarzyk P, Pietrobelli A, Redden DT, Ruden DM, Wang C, Waterland RA, Wright SM, Allison DB: Ten putative contributors to the obesity epidemic. Crit Rev Food Sci Nutr 2009, 49:868-913.

22. Wardle J, Carnell S, Haworth CM, Plomin R: Evidence for a strong genetic influence on childhood adiposity despite the force of the obesogenic environment. Am J Clin Nutr 2008, 87:398-404.

23. Reilly JJ, Armstrong J, Dorosty AR, Emmett PM, Ness A, Rogers I, Steer C, Sherriff A: Early life risk factors for obesity in childhood: cohort study. BMJ 2005, 330:1357

24. Pietilainen KH, Kaprio J, Rissanen A, Winter T, Rimpela A, Viken RJ, Rose RJ: Distribution and heritability of BMI in Finnish adolescents aged 16y and 17y: a study of 4884 twins and 2509 singletons. Int J Obes Relat Metab Disord 1999, 23:107-115.

25. Cai G, Cole SA, Butte NF, Smith CW, Mehta NR, Voruganti VS, Proffitt JM, Comuzzie AG: A genetic contribution to circulating cytokines and obesity in children. Cytokine 2008, 44:242-247.

26. Haworth CM, Carnell S, Meaburn EL, Davis OS, Plomin R, Wardle J: Increasing heritability of BMI and stronger associations with the FTO gene over childhood. Obesity (Silver Spring) 2008, 16:2663-2668.

27. Lajunen HR, Kaprio J, Keski-Rahkonen A, Rose RJ, Pulkkinen L, Rissanen A, Silventoinen K: Genetic and environmental effects on body mass index during adolescence: a prospective study among Finnish twins. Int J Obes (Lond) 2009, 33:559-567.

28. Martin LJ, Woo JG, Morrison JA: Evidence of shared genetic effects between pre- and postobesity epidemic BMI levels. Obesity (Silver Spring) 2009, doi:10.1038/oby.2009.394.

29. Salsberry PJ, Reagan PB: Effects of heritability, shared environment, and nonshared intrauterine conditions on child and adolescent BMI. Obesity (Silver Spring) 2010, doi:10.1038/oby.2009.485

30. Mustelin L, Silventoinen K, Pietilainen K, Rissanen A, Kaprio J: Physical activity reduces the influence of genetic effects on $\mathrm{BMI}$ and waist circumference: a study in young adult twins. Int J Obes (Lond) 2009, 33:29-36.

31. Farooqi IS, O'Rahilly S: Mutations in ligands and receptors of the leptinmelanocortin pathway that lead to obesity. Nat Clin Pract Endocrinol Metab 2008, 4:569-577.

32. Holder JL Jr, Butte NF, Zinn AR: Profound obesity associated with a balanced translocation that disrupts the SIM1 gene. Hum Mol Genet 2000, 9:101-108.

33. Ahituv N, Kavaslar N, Schackwitz W, Ustaszewska A, Martin J, Hebert S, Doelle H, Ersoy B, Kryukov G, Schmidt S, Yosef N, Ruppin E, Sharan R, Vaisse C, Sunyaev S, Dent R, Cohen J, McPherson R, Pennacchio LA: Medical sequencing at the extremes of human body mass. Am J Hum Genet 2007, 80:779-791.

34. Christodoulides C, Scarda A, Granzotto M, Milan G, Dalla Nora E, Keogh J, De Pergola G, Stirling H, Pannacciulli N, Sethi JK, Federspil G, Vidal-Puig A, Farooqi IS, O'Rahilly S, Vettor R: WNT10B mutations in human obesity. Diabetologia 2006, 49:678-684

35. Yeo GS, Connie Hung CC, Rochford J, Keogh J, Gray J, Sivaramakrishnan S, O'Rahilly S, Faroogi IS: A de novo mutation affecting human TrkB associated with severe obesity and developmental delay. Nat Neurosci 2004, 7:1187-1189.

36. Gray J, Yeo GS, Cox JJ, Morton J, Adlam AL, Keogh JM, Yanovski JA, El Gharbawy A, Han JC, Tung YC, Hodges JR, Raymond FL, O'Rahilly S, Farooqi IS: Hyperphagia, severe obesity, impaired cognitive function, and hyperactivity associated with functional loss of one copy of the brainderived neurotrophic factor (BDNF) gene. Diabetes 2006, 55:3366-3371.
37. Farooqi IS, Jebb SA, Langmack G, Lawrence E, Cheetham CH, Prentice AM, Hughes IA, McCamish MA, O'Rahilly S: Effects of recombinant leptin therapy in a child with congenital leptin deficiency. N Engl J Med 1999, 341:879-884.

38. Han JC, Liu QR, Jones M, Levinn RL, Menzie CM, Jefferson-George KS, AdlerWailes DC, Sanford EL, Lacbawan FL, Uhl GR, Rennert OM, Yanovski JA: Brainderived neurotrophic factor and obesity in the WAGR syndrome. N Engl J Med 2008, 359:918-927.

39. Gunay-Aygun M, Schwartz S, Heeger S, O'Riordan MA, Cassidy SB: The changing purpose of Prader-Willi syndrome clinical diagnostic criteria and proposed revised criteria. Pediatrics 2001, 108:E92.

40. Muller J, Stoetzel C, Vincent MC, Leitch CC, Laurier V, Danse JM, Helle S, Marion V, Bennouna-Greene V, Vicaire S, Megarbane A, Kaplan J, DrouinGarraud V, Hamdani M, Sigaudy S, Francannet C, Roume J, Bitoun P, Goldenberg A, Philip N, Odent S, Green J, Cossée M, Davis EE, Katsanis N, Bonneau D, Verloes A, Poch O, Mandel JL, Dollfus H: Identification of 28 novel mutations in the Bardet-Biedl syndrome genes: the burden of private mutations in an extensively heterogeneous disease. Hum Genet, 127:583-593.

41. Marshall JD, Bronson RT, Collin GB, Nordstrom AD, Maffei P, Paisey RB, Carey C Macdermott S, Russell-Eggitt I, Shea SE, Davis J, Beck S, Shatirishvili G, Mihai CM, Hoeltzenbein M, Pozzan GB, Hopkinson I, Sicolo N, Naggert JK, Nishina PM: New Alstrom syndrome phenotypes based on the evaluation of 182 cases. Arch Intern Med 2005, 165:675-683.

42. Seifert W, Holder-Espinasse M, Spranger S, Hoeltzenbein M, Rossier E, Dollfus H, Lacombe D, Verloes A, Chrzanowska KH, Maegawa GH, Chitayat D, Kotzot D, Huhle D, Meinecke P, Albrecht B, Mathijssen I, Leheup B, Raile K, Hennies $\mathrm{HC}$, Horn D: Mutational spectrum of $\mathrm{COH} 1$ and clinical heterogeneity in Cohen syndrome. J Med Genet 2006, 43:e22.

43. Sahoo T, del Gaudio D, German JR, Shinawi M, Peters SU, Person RE, Garnica A, Cheung SW, Beaudet AL: Prader-Willi phenotype caused by paternal deficiency for the HBII-85 C/D box small nucleolar RNA cluster. Nat Genet 2008, 40:719-721

44. de Smith AJ, Purmann C, Walters RG, Ellis RJ, Holder SE, Van Haelst MM, Brady AF, Fairbrother UL, Dattani M, Keogh JM, Henning E, Yeo GS, O'Rahilly S, Froguel P, Faroogi IS, Blakemore Al: A deletion of the HBII-85 class of smal nucleolar RNAs (snoRNAs) is associated with hyperphagia, obesity and hypogonadism. Hum Mol Genet 2009, 18:3257-3265.

45. Ansley SJ, Badano JL, Blacque OE, Hill J, Hoskins BE, Leitch CC, Kim JC, Ross AJ, Eichers ER, Teslovich TM, Mah AK, Johnsen RC, Cavender JC, Lewis RA, Leroux MR, Beales PL, Katsanis N: Basal body dysfunction is a likely cause of pleiotropic Bardet-Biedl syndrome. Nature 2003, 425:628-633.

46. Botstein D, Risch N: Discovering genotypes underlying human phenotypes: past successes for mendelian disease, future approaches for complex disease. Nat Genet 2003, 33 Suppl:228-237.

47. Rankinen T, Zuberi A, Chagnon YC, Weisnagel SJ, Argyropoulos G, Walts B, Perusse L, Bouchard C: The human obesity gene map: the 2005 update. Obesity (Silver Spring) 2006, 14:529-644.

48. Saar K, Geller F, Ruschendorf F, Reis A, Friedel S, Schauble N, Nurnberg P, Siegfried W, Goldschmidt HP, Schafer H, Ziegler A, Remschmidt H, Hinney A, Hebebrand J: Genome scan for childhood and adolescent obesity in German families. Pediatrics 2003, 111:321-327.

49. Meyre D, Lecoeur C, Delplanque J, Francke S, Vatin V, Durand E, Weill J, Dina C Froguel P: A genome-wide scan for childhood obesity-associated traits in French families shows significant linkage on chromosome 6q22.31-q23.2. Diabetes 2004, 53:803-811.

50. Chen W, Li S, Cook NR, Rosner BA, Srinivasan SR, Boerwinkle E, Berenson GS: An autosomal genome scan for loci influencing longitudinal burden of body mass index from childhood to young adulthood in white sibships: The Bogalusa Heart Study. Int J Obes Relat Metab Disord 2004, 28:462-469.

51. Meyre D, Bouatia-Naji N, Tounian A, Samson C, Lecoeur C, Vatin V, Ghoussain M, Wachter C, Hercberg S, Charpentier G, Patsch W, Pattou F, Charles MA Tounian P, Clément K, Jouret B, Weill J, Maddux BA, Goldfine ID, Walley A, Boutin P, Dina C, Froguel P: Variants of ENPP1 are associated with childhood and adult obesity and increase the risk of glucose intolerance and type 2 diabetes. Nat Genet 2005, 37:863-867.

52. Maddux BA, Goldfine ID: Membrane glycoprotein PC-1 inhibition of insulin receptor function occurs via direct interaction with the receptor alphasubunit. Diabetes 2000, 49:13-19.

53. Dong H, Maddux BA, Altomonte J, Meseck M, Accili D, Terkeltaub R, Johnson $\mathrm{K}$, Youngren JF, Goldfine ID: Increased hepatic levels of the insulin receptor inhibitor, PC-1/NPP1, induce insulin resistance and glucose intolerance. 
Diabetes 2005, 54:367-372.

54. Zhou HH, Chin CN, Wu M, Ni W, Quan S, Liu F, Dallas-Yang Q, Ellsworth K, Ho T, Zhang A, Natasha T, Li J, Chapman K, StrohI W, Li C, Wang IM, Berger J, An Z, Zhang BB, Jiang G: Suppression of PC-1/ENPP-1 expression improves insulin sensitivity in vitro and in vivo. Eur J Pharmacol 2009, 616:346-352.

55. Odeleye OE, de Courten M, Pettitt DJ, Ravussin E: Fasting hyperinsulinemia is a predictor of increased body weight gain and obesity in Pima Indian children. Diabetes 1997, 46:1341-1345.

56. Morrison JA, Glueck CJ, Horn PS, Schreiber GB, Wang P: Pre-teen insulin resistance predicts weight gain, impaired fasting glucose, and type 2 diabetes at age 18-19 y: a 10-y prospective study of black and white girls. Am J Clin Nutr 2008, 88:778-788.

57. Bottcher Y, Korner A, Reinehr T, Enigk B, Kiess W, Stumvoll M, Kovacs P: ENPP1 variants and haplotypes predispose to early onset obesity and impaired glucose and insulin metabolism in German obese children. J Clin Endocrinol Metab 2006, 91:4948-4952.

58. Morandi A, Pinelli L, Petrone A, Vatin V, Buzzetti R, Froguel P, Meyre D: The Q121 variant of ENPP1 may protect from childhood overweight/obesity in the Italian population. Obesity (Silver Spring) 2009, 17:202-206.

59. Altmuller J, Palmer LJ, Fischer G, Scherb H, Wist M: Genomewide scans of complex human diseases: true linkage is hard to find. Am J Hum Genet 2001, 69:936-950

60. Stutzmann F, Vatin V, Cauchi S, Morandi A, Jouret B, Landt O, Tounian P, LevyMarchal C, Buzzetti R, Pinelli L, Balkau B, Horber F, Bougnères $P$, Froguel $P$ Meyre D: Non-synonymous polymorphisms in melanocortin-4 receptor protect against obesity: the two facets of a Janus obesity gene. Hum Mol Genet 2007, 16:1837-1844.

61. Wang D, Ma J, Zhang S, Hinney A, Hebebrand J, Wang Y, Wang HJ: Association of the MC4R V103I polymorphism with obesity: a Chinese case-control study and meta-analysis in 55,195 individuals. Obesity (Silver Spring) 2010, 18:573-579.

62. Benzinou M, Creemers JW, Choquet H, Lobbens S, Dina C, Durand E, Guerardel A, Boutin P, Jouret B, Heude B, Balkau B, Tichet J, Marre M, Potoczna N, Horber F, Le Stunff C, Czernichow S, Sandbaek A, Lauritzen T, BorchJohnsen K, Andersen G, Kiess W, Körner A, Kovacs P, Jacobson P, Carlsson LM, Walley AJ, Jørgensen T, Hansen T, Pedersen O, Meyre D, Froguel P: Common nonsynonymous variants in PCSK1 confer risk of obesity. Nat Genet 2008, 40:943-945

63. Kilpelainen TO, Bingham SA, Khaw KT, Wareham NJ, Loos RJ: Association of variants in the PCSK1 gene with obesity in the EPIC-Norfolk study. Hum Mol Genet 2009, 18:3496-3501.

64. Willer CJ, Speliotes EK, Loos RJ, Li S, Lindgren CM, Heid IM, Berndt SI, Elliott AL, Jackson AU, Lamina C, Lettre G, Lim N, Lyon HN, McCarroll SA, Papadakis K, Qi L, Randall JC, Roccasecca RM, Sanna S, Scheet P, Weedon MN, Wheeler E, Zhao JH, Jacobs LC, Prokopenko I, Soranzo N, Tanaka T, Timpson NJ, Almgren $P$, Bennett A, et al: Six new loci associated with body mass index highlight a neuronal influence on body weight regulation. Nat Genet 2009, 41:25-34.

65. Jackson RS, Creemers JW, Ohagi S, Raffin-Sanson ML, Sanders L, Montague $\mathrm{CT}$, Hutton JC, O'Rahilly S: Obesity and impaired prohormone processing associated with mutations in the human prohormone convertase 1 gene. Nat Genet 1997, 16:303-306

66. Vaisse C, Clement K, Guy-Grand B, Froguel P: A frameshift mutation in human MC4R is associated with a dominant form of obesity. Nat Genet 1998, 20:113-114

67. Yeo GS, Faroogi IS, Aminian S, Halsall DJ, Stanhope RG, O'Rahilly S: A frameshift mutation in MC4R associated with dominantly inherited human obesity. Nat Genet 1998, 20:111-112.

68. Benzinou M, Chevre JC, Ward KJ, Lecoeur C, Dina C, Lobbens S, Durand E, Delplanque J, Horber FF, Heude B, Balkau B, Borch-Johnsen K, Jørgensen T, Hansen T, Pedersen O, Meyre D, Froguel P: Endocannabinoid receptor 1 gene variations increase risk for obesity and modulate body mass index in European populations. Hum Mol Genet 2008, 17:1916-1921.

69. Gazzerro P, Caruso MG, Notarnicola M, Misciagna G, Guerra V, Laezza C, Bifulco M: Association between cannabinoid type-1 receptor polymorphism and body mass index in a southern Italian population. Int J Obes (Lond) 2007, 31:908-912.

70. Russo P, Strazzullo P, Cappuccio FP, Tregouet DA, Lauria F, Loguercio M, Barba $\mathrm{G}$, Versiero M, Siani A: Genetic variations at the endocannabinoid type 1 receptor gene (CNR1) are associated with obesity phenotypes in men. J Clin Endocrinol Metab 2007, 92:2382-2386.

71. Peeters A, Beckers S, Mertens I, Van Hul W, Van Gaal L: The G1422A variant of the cannabinoid receptor gene (CNR1) is associated with abdominal adiposity in obese men. Endocrine 2007, 31:138-141.

72. Jaeger JP, Mattevi VS, Callegari-Jacques SM, Hutz MH: Cannabinoid type-1 receptor gene polymorphisms are associated with central obesity in a Southern Brazilian population. Dis Markers 2008, 25:67-74.

73. Aberle J, Flitsch J, Beck NA, Mann O, Busch P, Peitsmeier P, Beil FU: Genetic variation may influence obesity only under conditions of diet: analysis of three candidate genes. Mol Genet Metab 2008, 95:188-191.

74. Frazer KA, Ballinger DG, Cox DR, Hinds DA, Stuve LL, Gibbs RA, Belmont JW, Boudreau A, Hardenbol P, Leal SM, Pasternak S, Wheeler DA, Willis TD, Yu F, Yang H, Zeng C, Gao Y, Hu H, Hu W, Li C, Lin W, Liu S, Pan H, Tang X, Wang J, Wang W, Yu J, Zhang B, Zhang Q, Zhao H, et al:: A second generation human haplotype map of over 3.1 million SNPs. Nature 2007, 449:851-861.

75. Hao K, Schadt EE, Storey JD: Calibrating the performance of SNP arrays for whole-genome association studies. PLoS Genet 2008, 4:e1000109.

76. Hirschhorn JN: Genomewide association studies - illuminating biologic pathways. N Eng/ J Med 2009, 360:1699-1701.

77. Hofker M, Wijmenga C: A supersized list of obesity genes. Nat Genet 2009, 41:139-140.

78. Hinney A, Nguyen TT, Scherag A, Friedel S, Bronner G, Muller TD, Grallert H, Illig T, Wichmann HE, RiefW, Schäfer H, Hebebrand J: Genome wide association (GWA) study for early onset extreme obesity supports the role of fat mass and obesity associated gene (FTO) variants. PLOS ONE 2007, 2:e1361.

79. Frayling TM, Timpson NJ, Weedon MN, Zeggini E, Freathy RM, Lindgren CM, Perry JR, Elliott KS, Lango H, Rayner NW, Shields B, Harries LW, Barrett JC, Ellard S, Groves CJ, Knight B, Patch AM, Ness AR, Ebrahim S, Lawlor DA, Ring SM, Ben-Shlomo Y, Jarvelin MR, Sovio U, Bennett AJ, Melzer D, Ferrucci L, Loos RJ, Barroso I, Wareham NJ, et al: A common variant in the FTO gene is associated with body mass index and predisposes to childhood and adult obesity. Science 2007, 316:889-894.

80. Scuteri A, Sanna S, Chen WM, Uda M, Albai G, Strait J, Najjar S, Nagaraja R, Orru M, Usala G, Dei M, Lai S, Maschio A, Busonero F, Mulas A, Ehret GB, Fink AA, Weder AB, Cooper RS, Galan P, Chakravarti A, Schlessinger D, Cao A, Lakatta E, Abecasis GR: Genome-wide association scan shows genetic variants in the FTO gene are associated with obesity-related traits. PLOS Genet 2007, 3:e115.

81. Dina C, Meyre D, Gallina S, Durand E, Korner A, Jacobson P, Carlsson LM, Kiess W, Vatin V, Lecoeur C, Delplanque J, Vaillant E, Pattou F, Ruiz J, Weill J, LevyMarchal C, Horber F, Potoczna N, Hercberg S, Le Stunff C, Bougnères P, Kovacs P, Marre M, Balkau B, Cauchi S, Chèvre JC, Froguel P: Variation in FTO contributes to childhood obesity and severe adult obesity. Nat Genet 2007, 39:724-726.

82. Meyre D, Delplanque J, Chevre JC, Lecoeur C, Lobbens S, Gallina S, Durand E, Vatin V, Degraeve F, Proenca C, Gaget S, Körner A, Kovacs P, Kiess W, Tichet J, Marre M, Hartikainen AL, Horber F, Potoczna N, Hercberg S, Levy-Marchal C, Pattou F, Heude B, Tauber M, McCarthy MI, Blakemore Al, Montpetit A, Polychronakos C, Weill J, Coin L, et al: Genome-wide association study for early-onset and morbid adult obesity identifies three new risk loci in European populations. Nat Genet 2009, 41:157-159.

83. Loos RJ, Lindgren CM, Li S, Wheeler E, Zhao JH, Prokopenko I, Inouye M, Freathy RM, Attwood AP, Beckmann JS, Berndt SI; Prostate, Lung, Colorectal, and Ovarian (PLCO) Cancer Screening Trial, Jacobs KB, Chanock SJ, Hayes RB, Bergmann S, Bennett AJ, Bingham SA, Bochud M, Brown M, Cauchi S, Connell JM, Cooper C, Smith GD, Day I, Dina C, De S, Dermitzakis ET, Doney AS, Elliott $\mathrm{KS}$, et al: Common variants near MC4R are associated with fat mass, weight and risk of obesity. Nat Genet 2008, 40:768-775

84. Chambers JC, Elliott P, Zabaneh D, Zhang W, Li Y, Froguel P, Balding D, Scott J, Kooner JS: Common genetic variation near MC4R is associated with waist circumference and insulin resistance. Nat Genet 2008, 40:716-718.

85. Scherag A, Dina C, Hinney A, Vatin V, Scherag S, Vogel Cl, Muller TD, Grallert H, Wichmann HE, Balkau B, Heude B, Jarvelin MR, Hartikainen AL, Levy-Marchal C, Weill J, Delplanque J, Körner A, Kiess W, Kovacs P, Rayner NW, Prokopenko I, McCarthy MI, Schäfer H, Jarick I, Boeing H, Fisher E, Reinehr T, Heinrich J, Rzehak P, Berdel D, et al:: Two new loci for body-weight regulation identified in a joint analysis of genome-wide association studies for early-onset extreme obesity in French and German study groups. PLoS Genet 2010, 6:e1000916

86. Lindgren CM, Heid IM, Randall JC, Lamina C, Steinthorsdottir V, Qi L, Speliotes EK, Thorleifsson G, Willer CJ, Herrera BM, Jackson AU, Lim N, Scheet P, Soranzo $\mathrm{N}$, Amin N, Aulchenko YS, Chambers JC, Drong A, Luan J, Lyon HN, 
Rivadeneira F, Sanna S, Timpson NJ, Zillikens MC, Zhao JH, Almgren P, Bandinelli S, Bennett AJ, Bergman RN, Bonnycastle LL, et al.: Genome-wide association scan meta-analysis identifies three loci influencing adiposity and fat distribution. PLoS Genet 2009, 5:e1000508.

87. Thorleifsson G, Walters GB, Gudbjartsson DF, Steinthorsdottir $V_{\text {, Sulem } P \text {, }}$ Helgadottir A, Styrkarsdottir U, Gretarsdottir S, Thorlacius S, Jonsdottir I, Jonsdottir T, Olafsdottir EJ, Olafsdottir GH, Jonsson T, Jonsson F, BorchJohnsen K, Hansen T, Andersen G, Jorgensen T, Lauritzen T, Aben KK, Verbeek AL, Roeleveld N, Kampman E, Yanek LR, Becker LC, Tryggvadottir L, Rafnar T, Becker DM, Gulcher J, et al:: Genome-wide association yields new sequence variants at seven loci that associate with measures of obesity. Nat Genet 2009, 41:18-24.

88. Zhao J, Bradfield JP, Li M, Wang K, Zhang H, Kim CE, Annaiah K, Glessner JT, Thomas K, Garris M, Frackelton EC, Otieno FG, Shaner JL, Smith RM, Chiavacci RM, Berkowitz RI, Hakonarson H, Grant SF: The role of obesity-associated loci identified in genome-wide association studies in the determination of pediatric BMI. Obesity (Silver Spring) 2009, 17:2254-2257.

89. Conrad DF, Pinto D, Redon R, Feuk L, Gokcumen O, Zhang Y, Aerts J, Andrews TD, Barnes C, Campbell P, Fitzgerald T, Hu M, Ihm CH, Kristiansson K, Macarthur DG, Macdonald JR, Onyiah I, Pang AW, Robson S, Stirrups K, Valsesia A, Walter K, Wei J; Wellcome Trust Case Control Consortium, TylerSmith C, Carter NP, Lee C, Scherer SW, Hurles ME: Origins and functional impact of copy number variation in the human genome. Nature, 464:704-712.

90. Bochukova EG, Huang N, Keogh J, Henning E, Purmann C, Blaszczyk K, Saeed S, Hamilton-Shield J, Clayton-Smith J, O'Rahilly S, Hurles ME, Faroogi IS: Large, rare chromosomal deletions associated with severe early-onset obesity. Nature, 463:666-670

91. Walters RG, Jacquemont S, Valsesia A, de Smith AJ, Martinet D, Andersson J, Falchi M, Chen F, Andrieux J, Lobbens S, Delobel B, Stutzmann F, El-Sayed Moustafa JS, Chèvre JC, Lecoeur C, Vatin V, Bouquillon S, Buxton JL, Boute O, Holder-Espinasse M, Cuisset JM, Lemaitre MP, Ambresin AE, Brioschi A, Gaillard M, Giusti V, Fellmann F, Ferrarini A, Hadjikhani N, Campion D, et al.: A new highly penetrant form of obesity due to deletions on chromosome 16p11.2. Nature 2010, 463:671-675.

92. Weiss LA, Shen Y, Korn JM, Arking DE, Miller DT, Fossdal R, Saemundsen E, Stefansson H, Ferreira MA, Green T, Platt OS, Ruderfer DM, Walsh CA, Altshuler D, Chakravarti A, Tanzi RE, Stefansson K, Santangelo SL, Gusella JF, Sklar P, Wu BL, Daly MJ; Autism Consortium: Association between microdeletion and microduplication at 16p11.2 and autism. N Engl J Med 2008, 358:667-675.

93. Marshall CR, Noor A, Vincent JB, Lionel AC, Feuk L, Skaug J, Shago M, Moessner R, Pinto D, Ren Y, Thiruvahindrapduram B, Fiebig A, Schreiber S, Friedman J, Ketelaars CE, Vos YJ, Ficicioglu C, Kirkpatrick S, Nicolson R, Sloman L, Summers A, Gibbons CA, Teebi A, Chitayat D, Weksberg R, Thompson A, Vardy C, Crosbie V, Luscombe S, Baatjes R, et al.: Structural variation of chromosomes in autism spectrum disorder. Am J Hum Genet 2008, 82:477-488.

94. McCarthy SE, Makarov V, Kirov G, Addington AM, McClellan J, Yoon S, Perkins DO, Dickel DE, Kusenda M, Krastoshevsky O, Krause V, Kumar RA, Grozeva D, Malhotra D, Walsh T, Zackai EH, Kaplan P, Ganesh J, Krantz ID, Spinner NB, Roccanova P, Bhandari A, Pavon K, Lakshmi B, Leotta A, Kendall J, Lee YH, Vacic V, Gary S, lakoucheva LM, et al.: Microduplications of 16p11.2 are associated with schizophrenia. Nat Genet 2009, 41:1223-1227.

95. Bijlsma EK, Gijsbers AC, Schuurs-Hoeijmakers JH, van Haeringen A, Fransen van de Putte DE, Anderlid BM, Lundin J, Lapunzina P, Perez Jurado LA, Delle Chiaie B, Loeys B, Menten B, Oostra A, Verhelst H, Amor DJ, Bruno DL, van Essen AJ, Hordijk R, Sikkema-Raddatz B, Verbruggen KT, Jongmans MC, Pfundt $\mathrm{R}$, Reeser HM, Breuning MH, Ruivenkamp CA: Extending the phenotype of recurrent rearrangements of $16 \mathrm{p} 11.2$ : deletions in mentally retarded patients without autism and in normal individuals. Eur J Med Genet 2009, 52:77-87.

96. Fernandez BA, Roberts W, Chung B, Weksberg R, Meyn S, Szatmari P, JosephGeorge AM, Mackay S, Whitten K, Noble B, Vardy C, Crosbie V, Luscombe S, Tucker E, Turner L, Marshall CR, Scherer SW: Phenotypic spectrum associated with de novo and inherited deletions and duplications at 16p11.2 in individuals ascertained for diagnosis of autism spectrum disorder. J Med Genet, 47:195-203.

97. Ren D, Li M, Duan C, Rui L: Identification of SH2-B as a key regulator of leptin sensitivity, energy balance, and body weight in mice. Cell Metab 2005, 2:95-104.

98. Ren D, Zhou Y, Morris D, Li M, Li Z, Rui L: Neuronal SH2B1 is essential for controlling energy and glucose homeostasis. J Clin Invest 2007, 117:397-406.

99. Sonestedt E, Roos C, Gullberg B, Ericson U, Wirfalt E, Orho-Melander M: Fat and carbohydrate intake modify the association between genetic variation in the FTO genotype and obesity. Am J Clin Nutr 2009, 90:1418-1425.

100. Corella D, Peloso G, Arnett DK, Demissie S, Cupples LA, Tucker K, Lai CQ, Parnell LD, Coltell O, Lee YC, Ordovas JM: APOA2, dietary fat, and body mass index: replication of a gene-diet interaction in 3 independent populations. Arch Intern Med 2009, 169:1897-1906.

101. Andreasen CH, Stender-Petersen KL, Mogensen MS, Torekov SS, Wegner L, Andersen G, Nielsen AL, Albrechtsen A, Borch-Johnsen K, Rasmussen SS, Clausen JO, Sandbaek A, Lauritzen T, Hansen L, Jørgensen T, Pedersen O, Hansen T: Low physical activity accentuates the effect of the FTO rs 9939609 polymorphism on body fat accumulation. Diabetes 2008, 57:95-101.

102. Rampersaud E, Mitchell BD, Pollin TI, Fu M, Shen H, O'Connell JR, Ducharme JL, Hines S, Sack P, Naglieri R, Shuldiner AR, Snitker S: Physical activity and the association of common FTO gene variants with body mass index and obesity. Arch Intern Med 2008, 168:1791-1797.

103. Cauchi S, Stutzmann F, Cavalcanti-Proenca C, Durand E, Pouta A, Hartikainen AL, Marre M, Vol S, Tammelin T, Laitinen J, Gonzalez-Izquierdo A, Blakemore Al, Elliott P, Meyre D, Balkau B, Järvelin MR, Froguel P: Combined effects of MC4R and FTO common genetic variants on obesity in European general populations. J Mol Med 2009, 87:537-546.

104. Vimaleswaran KS, Li S, Zhao JH, Luan J, Bingham SA, Khaw KT, Ekelund U, Wareham NJ, Loos RJ: Physical activity attenuates the body mass indexincreasing influence of genetic variation in the FTO gene. Am J Clin Nutr 2009, 90:425-428.

105. Karasawa S, Daimon M, Sasaki S, Toriyama S, Oizumi T, Susa S, Kameda W, Wada K, Muramatsu M, Fukao A, Kubota I, Kawata S, Kayama T, Kato T: Association of the common fat mass and obesity associated (FTO) gene polymorphism with obesity in a Japanese population. Endocr J 2010, 57:293-301.

106. Ruiz JR, Labayen I, Ortega FB, Legry V, Moreno LA, Dallongeville J, MartinezGomez D, Bokor S, Manios Y, Ciarapica D, Gottrand F, De Henauw S, Molnár D, Sjöström M, Meirhaeghe A; HELENA Study Group: Attenuation of the effect of the FTO rs9939609 polymorphism on total and central body fat by physical activity in adolescents: the HELENA study. Arch Pediatr Adolesc Med 2010, 164:328-333.

107. Jacobsson JA, Riserus U, Axelsson T, Lannfelt L, Schioth HB, Fredriksson R The common FTO variant rs9939609 is not associated with BMI in a longitudinal study on a cohort of Swedish men born 1920-1924. BMC Med Genet 2009, 10:131

108. Mitchell JA, Church TS, Rankinen T, Earnest CP, Sui X, Blair SN: FTO genotype and the weight loss benefits of moderate intensity exercise. Obesity (Silver Spring) 2010, 18:641-643.

109. Luan J, Kerner B, Zhao JH, Loos RJ, Sharp SJ, Muthen BO, Wareham NJ: A multilevel linear mixed model of the association between candidate genes and weight and body mass index using the Framingham longitudinal family data. BMC Proc 2009, 3 Suppl 7:S115.

110. Stutzmann F, Tan K, Vatin V, Dina C, Jouret B, Tichet J, Balkau B, Potoczna N, Horber F, O'Rahilly S, Faroogi IS, Froguel P, Meyre D: Prevalence of melanocortin-4 receptor deficiency in Europeans and their agedependent penetrance in multigenerational pedigrees. Diabetes 2008 , $57: 2511-2518$

111. Stone S, Abkevich V, Russell DL, Riley R, Timms K, Tran T, Trem D, Frank D, Jammulapati S, Neff CD, lliev D, Gress R, He G, Frech GC, Adams TD, Skolnick MH, Lanchbury JS, Gutin A, Hunt SC, Shattuck D: TBC1D1 is a candidate for a severe obesity gene and evidence for a gene/gene interaction in obesity predisposition. Hum Mol Genet 2006, 15:2709-2720.

112. Meyre D, Farge M, Lecoeur C, Proenca C, Durand E, Allegaert F, Tichet J, Marre M, Balkau B, Weill J, Delplanque J, Froguel P: R125W coding variant in TBC1D1 confers risk for familial obesity and contributes to linkage on chromosome 4p14 in the French population. Hum Mol Genet 2008, 17:1798-1802

113. Dempfle A, Hinney A, Heinzel-Gutenbrunner M, Raab M, Geller F, Gudermann T, Schafer H, Hebebrand J: Large quantitative effect of melanocortin-4 receptor gene mutations on body mass index. J Med Genet 2004, 41:795-800.

114. Traurig M, Mack J, Hanson RL, Ghoussaini M, Meyre D, Knowler WC, Kobes S, 
Froguel P, Bogardus C, Baier L: Common variation in SIM1 is reproducibly associated with BMI in Pima Indians. Diabetes 2009, 58:1682-1689.

115. Ghoussaini M, Stutzmann F, Couturier C, Vatin V, Durand E, Lecoeur C, Degraeve F, Heude B, Tauber M, Hercberg S, Levy-Marchal C, Tounian P, Weill J, Traurig M, Bogardus C, Baier L, Michaud JL, Froguel P, Meyre D: Analysis of the SIM1 Contribution to Polygenic Obesity in the French Population. Obesity (Silver Spring) 2010, doi:10.1038/oby.2009.468.

116. Gomez-Ambrosi J, Catalan V, Diez-Caballero A, Martinez-Cruz LA, Gil MJ, Garcia-Foncillas J, Cienfuegos JA, Salvador J, Mato JM, Fruhbeck G: Gene expression profile of omental adipose tissue in human obesity. FASEB J 2004, 18:215-217.

117. Clement K, Viguerie N, Poitou C, Carette C, Pelloux V, Curat CA, Sicard A, Rome S, Benis A, Zucker JD, Vidal H, Laville M, Barsh GS, Basdevant A, Stich V, Cancello R, Langin D: Weight loss regulates inflammation-related genes in white adipose tissue of obese subjects. FASEB J 2004, 18:1657-1669.

118. Shea J, French CR, Bishop J, Martin G, Roebothan B, Pace D, Fitzpatrick D, Sun $\mathrm{G}$ : Changes in the transcriptome of abdominal subcutaneous adipose tissue in response to short-term overfeeding in lean and obese men. Am J Clin Nutr 2009, 89:407-415.

119. Leonardson AS, Zhu J, Chen Y, Wang K, Lamb JR, Reitman M, Emilsson V, Schadt EE: The effect of food intake on gene expression in human peripheral blood. Hum Mol Genet, 19:159-169.

120. De Giorgio MR, Yoshioka M, St-Amand J: Feeding induced changes in the hypothalamic transcriptome. Clin Chim Acta 2009, 406:103-107.

121. Mutch DM, Temanni MR, Henegar C, Combes F, Pelloux V, Holst C, Sorensen TI, Astrup A, Martinez JA, Saris WH, Viguerie N, Langin D, Zucker JD, Clément K: Adipose gene expression prior to weight loss can differentiate and weakly predict dietary responders. PLOS ONE 2007, 2:e1344.

122. Sieberts SK, Schadt EE: Moving toward a system genetics view of disease. Mamm Genome 2007, 18:389-401.

123. Schadt EE, Lamb J, Yang X, Zhu J, Edwards S, Guhathakurta D, Sieberts SK, Monks S, Reitman M, Zhang C, Lum PY, Leonardson A, Thieringer R, Metzger JM, Yang L, Castle J, Zhu H, Kash SF, Drake TA, Sachs A, Lusis AJ: An integrative genomics approach to infer causal associations between gene expression and disease. Nat Genet 2005, 37:710-717.

124. Mehrabian M, Allayee H, Stockton J, Lum PY, Drake TA, Castellani LW, Suh M, Armour C, Edwards S, Lamb J, Lusis AJ, Schadt EE: Integrating genotypic and expression data in a segregating mouse population to identify 5-lipoxygenase as a susceptibility gene for obesity and bone traits. Nat Genet 2005, 37:1224-1233.

125. Yang X, Deignan JL, Qi H, Zhu J, Qian S, Zhong J, Torosyan G, Majid S, Falkard B, Kleinhanz RR, Karlsson J, Castellani LW, Mumick S, Wang K, Xie T, Coon M, Zhang C, Estrada-Smith D, Farber CR, Wang SS, van Nas A, Ghazalpour A, Zhang B, Macneil DJ, Lamb JR, Dipple KM, Reitman ML, Mehrabian M, Lum PY, Schadt EE, et al:: Validation of candidate causal genes for obesity that affect shared metabolic pathways and networks. Nat Genet 2009, 41:415-423.

126. Chen Y, Zhu J, Lum PY, Yang X, Pinto S, MacNeil DJ, Zhang C, Lamb J, Edwards S, Sieberts SK, Leonardson A, Castellini LW, Wang S, Champy MF, Zhang B, Emilsson V, Doss S, Ghazal pour A, Horvath S, Drake TA, Lusis AJ, Schadt EE: Variations in DNA elucidate molecular networks that cause disease. Nature 2008, 452:429-435.

127. Emilsson V, Thorleifsson G, Zhang B, Leonardson AS, Zink F, Zhu J, Carlson S, Helgason A, Walters GB, Gunnarsdottir S, Mouy M, Steinthorsdottir V, Eiriksdottir GH, Bjornsdottir G, Reynisdottir I, Gudbjartsson D, Helgadottir A, Jonasdottir A, Jonasdottir A, Styrkarsdottir U, Gretarsdottir S, Magnusson KP, Stefansson H, Fossdal R, Kristjansson K, Gislason HG, Stefansson T, Leifsson BG, Thorsteinsdottir U, Lamb JR, et al.: Genetics of gene expression and its effect on disease. Nature 2008, 452:423-428.

128. Backhed F, Ding H, Wang T, Hooper LV, Koh GY, Nagy A, Semenkovich CF, Gordon J: The gut microbiota as an environmental factor that regulates fat storage. Proc Natl Acad Sci USA 2004, 101:15718-15723.

129. Turnbaugh PJ, Ley RE, Mahowald MA, Magrini V, Mardis ER, Gordon Jl: An obesity-associated gut microbiome with increased capacity for energy harvest. Nature 2006, 444:1027-1031.
130. Ley RE, Turnbaugh PJ, Klein S, Gordon Jl: Microbial ecology: human gut microbes associated with obesity. Nature 2006, 444:1022-1023.

131. Turnbaugh PJ, Hamady M, Yatsunenko T, Cantarel BL, Duncan A, Ley RE, Sogin ML, Jones WJ, Roe BA, Affourtit JP, Egholm M, Henrissat B, Heath AC, Knight R, Gordon Jl: A core gut microbiome in obese and lean twins. Nature 2009, 457:480-484.

132. Balamurugan R, George G, Kabeerdoss J, Hepsiba J, Chandragunasekaran AM, Ramakrishna BS: Quantitative differences in intestinal Faecalibacterium prausnitzii in obese Indian children. Br J Nutr 2010, 103:335-338.

133. Kalliomaki M, Collado MC, Salminen S, Isolauri E: Early differences in fecal microbiota composition in children may predict overweight. Am J Clin Nutr 2008, 87:534-538.

134. Qin J, Li R, Raes J, Arumugam M, Burgdorf KS, Manichanh C, Nielsen T, Pons N, Levenez F, Yamada T, Mende DR, Li J, Xu J, Li S, Li D, Cao J, Wang B, Liang H, Zheng H, Xie Y, Tap J, Lepage P, Bertalan M, Batto JM, Hansen T, Le Paslier D, Linneberg A, Nielsen HB, Pelletier E, Renault P, et al:: A human gut microbial gene catalogue established by metagenomic sequencing. Nature 2010, 464:59-65.

135. Wray NR, Goddard ME, Visscher PM: Prediction of individual genetic risk of complex disease. Curr Opin Genet Dev 2008, 18:257-263.

136. Li S, Zhao JH, Luan J, Luben RN, Rodwell SA, Khaw KT, Ong KK, Wareham NJ, Loos RJ: Cumulative effects and predictive value of common obesitysusceptibility variants identified by genome-wide association studies. Am J Clin Nutr 2010, 91:184-190.

137. Sandholt CH, Sparso T, Grarup N, Albrechtsen A, Almind K, Hansen L, Toft U, Jorgensen T, Hansen T, Pedersen O: Combined analyses of 20 common obesity susceptibility variants. Diabetes 2010, doi:10.2337/db09-1042.

138. Wei Z, Wang K, Qu HQ, Zhang H, Bradfield J, Kim C, Frackleton E, Hou C, Glessner JT, Chiavacci R, Stanley C, Monos D, Grant SF, Polychronakos C, Hakonarson $\mathrm{H}$ : From disease association to risk assessment: an optimistic view from genome-wide association studies on type 1 diabetes. PLoS Genet 2009, 5:e1000678.

139. Manolio TA, Collins FS, Cox NJ, Goldstein DB, Hindorff LA, Hunter DJ, McCarthy MI, Ramos EM, Cardon LR, Chakravarti A, Cho JH, Guttmacher AE, Kong A, Kruglyak L, Mardis E, Rotimi CN, Slatkin M, Valle D, Whittemore AS, Boehnke M, Clark AG, Eichler EE, Gibson G, Haines JL, Mackay TF, McCarroll SA, Visscher PM: Finding the missing heritability of complex diseases. Nature 2009, 461:747-753.

140. Stone S, Abkevich V, Hunt SC, Gutin A, Russell DL, Neff CD, Riley R, Frech GC, Hensel CH, Jammulapati S, Potter J, Sexton D, Tran T, Gibbs D, lliev D, Gress R, Bloomquist B, Amatruda J, Rae PM, Adams TD, Skolnick MH, Shattuck D: A major predisposition locus for severe obesity, at 4p15-p14. Am J Hum Genet 2002, 70:1459-1468.

141. Harville HM, Held S, Diaz-Font A, Davis EE, Diplas BH, Lewis RA, Borochowitz ZU, Zhou W, Chaki M, Macdonald J, Kayserili H, Beales PL, Katsanis N, Otto E, Hildebrandt F: Identification of 11 novel mutations in 8 BBS genes by highresolution homozygosity mapping. J Med Genet 2010, 47:262-267.

142. Ng SB, Buckingham KJ, Lee C, Bigham AW, Tabor HK, Dent KM, Huff CD, Shannon PT, Jabs EW, Nickerson DA, Shendure J, Bamshad MJ: Exome sequencing identifies the cause of a Mendelian disorder. Nat Genet 2009, 42:30-35.

143. Ashley EA, Butte AJ, Wheeler MT, Chen R, Klein TE, Dewey FE, Dudley JT, Ormond KE, Pavlovic A, Morgan AA, Pushkarev D, Neff NF, Hudgins L, Gong L, Hodges LM, Berlin DS, Thorn CF, Sangkuhl K, Hebert JM, Woon M, Sagreiya H, Whaley R, Knowles JW, Chou MF, Thakuria JV, Rosenbaum AM, Zaranek AW, Church GM, Greely HT, Quake SR, et al:: Clinical assessment incorporating a personal genome. Lancet 2010, 375:1525-1535.

doi:10.1186/gm157

Cite this article as: Choquet H, Meyre D: Genomic insights into early-onset obesity. Genome Medicine 2010, 2:36. 